Volume 6, Nomor 4, Tahun 2017, Halaman 319-325

Online di : http://ejournal-s1.undip.ac.id/index.php/jnc

\title{
HUBUNGAN OBESITAS SENTRAL DENGAN SIKLUS MENSTRUASI DAN DYSMENORRHEA PRIMER PADA REMAJA
}

\author{
Else Karina $S^{1}$, Nuryanto ${ }^{1}$, Aryu Candra ${ }^{1}$ \\ ${ }^{1}$ Departemen Ilmu Gizi Fakultas Kedokteran Universitas Diponegoro \\ Jln. Prof. H. Soedarto, SH., Semarang, Telp (024) 8453708, Email : gizifk@ undip.ac.id
}

\begin{abstract}
Background: Irregular menstrual cycle and primary Dysmenorrhea are menstrual disorder which woman can sustain. These can be occur because nutritional status especially obesity. Central obesity increase in adolescent which describe high body fat mass. High percentage of body fat mass in central obese patients can lead to hormonal dysfuntion and causing abnormal menstrual cycles and primary Dysmenorrhea.

Objective: To analyze the association of central obesity with menstrual cycle and primary dysmenorrhea in adolescents Methods : this study used Cross sectional design with 73 subject central obesity and 73 normal adolescent based on waist circumference. Anthropometric measurements include height, weight and waist circumference. Physical activity assessed by GPAQ physical activity questionnaire, family history Dysmenorrhea, menstrual cycle and primary Dysmenorrhea were assessed by questionnaire. Data were analyzed by Chi Square test.

Results: There were 23 adolescents or $31.5 \%$ of central obesity group have abnormal menstrual cycle whereas in normal group there were 10 adolescent or $13.6 \%$ who have abnormal menstrual cycle. There was association between central obesity and menstrual cycle $(p=0.018)$. There were 20 adolescents or $27.3 \%$ central obesity group have primary Dysmenorrhea whereas in normal group there were 15 adolescents or $20.5 \%$. There was no significant association between central obesity and primary Dysmenorrhea $(p=0.43)$.

Conclusion: There was association between central obesity and menstrual cycle but there was not association between central obesity and menstrual cycle

Keywords : Central obesity, menstrual cycle, primary Dysmenorrhea
\end{abstract}

\begin{abstract}
ABSTRAK
Latar Belakang: Wanita usia subur sering mengalami masalah siklus menstruasi yang tidak normal dan Dysmenorrhea primer. Persentasi lemak tubuh yang tinggi pada penderita obesitas sentral dapat mengakibatkan gangguan fungsi hormon yang menyebabkan terjadinya siklus menstruasi yang tidak normal dan Dysmenorrhea primer.

Tujuan: Menganalisis hubungan obesitas sentral dengan siklus menstruasi dan Dysmenorrhea primer pada remaja

Metode: Penelitian ini merupakan penelitian observasional dengan desain cross sectional. Subjek penelitian terdiri dari dua kelompok yaitu kelompok obesitas sentral dan kelompok normal berdasarkan lingkar pinggang dengan jumlah sampel masing-masing kelompok sebanyak 73 orang. Pengukuran antropometri meliputi pengukuran tinggi badan, berat badan dan lingkar pinggang. Pengukuran aktivitas fisik menggunakan kuesioner aktivitas fisik GPAQ, serta penilaian riwayat Dysmenorrhea keluarga, siklus menstruasi dan Dysmenorrhea primer melalui wawancara menggunakan kuesioner. Data dianalisis dengan uji Chi Square.

Hasil: Sebanyak 23 orang atau 31.5\% remaja yang menderita obesitas mengalami siklus menstruasi tidak normal sedangkan kelompok remaja status gizi normal dan mengalami siklus menstruasi tidak normal hanya 10 orang atau 13.6 \%. Terdapat hubungan antara obesitas sentral dengan siklus menstruasi $(p=0.018)$. Sebanyak 20 orang atau $27.3 \%$ kelompok obesitas sentral mengalami Dysmenorrhea primer dibandingkan dengan kelompok status gizi normal sebanyak 15 orang atau $20.5 \%$. Tidak ada hubungan yang bermakna antara obesitas sentral dengan kejadian Dysmenorrhea $\operatorname{primer}(p=0.43)$.
\end{abstract}

Simpulan: Obesitas sentral berhubungan dengan siklus menstruasi pada remaja. Sedangkan tidak terdapat hubungan antara obesitas sentral dengan Dysmenorrhea primer.

Kata kunci: Obesitas sentral, siklus menstruasi, Dysmenorrhea primer

\section{PENDAHULUAN}

Obesitas sentral atau yang juga dikenal dengan obesitas abdominal merupakan salah satu masalah kesehatan yang umum dengan kondisi kelebihan lemak yang terpusat pada daerah perut (intra-abdominal fat). Peningkatan risiko kesehatan lebih berhubungan dengan obesitas sentral dibandingkan dengan obesitas umum. ${ }^{1,2}$
Tingginya akumulasi lemak, terutama pada daerah perut (intra-abdominal fat) memicu jaringan adiposa menghasilkan hormon dalam jumlah yang tidak normal. Obesitas sentral dapat meningkatkan risiko siklus menstruasi tidak normal karena kelebihan lemak tubuh pada remaja akan menyebabkan produksi hormon yang berperan dalam siklus menstruasi menjadi tidak normal. Ketidakseimbangan hormon-hormon yang bekerja 
saat terjadinya siklus menstruasi akan menyebabkan terjadinya gangguan siklus menstruasi dan terjadinya Dysmenorrhea. ${ }^{1,2}$

Menstruasi dapat terjadi karena adanya peran dari beberapa hormon yang terdapat didalam tubuh khususnya hormon reproduksi pada wanita seperti esterogen, progesterone, FSH dan LH. Perubahan panjang dan keteraturan siklus menstruasi menunjukkan adanya perubahan produksi hormon yang bekerja pada saat menstruasi atau hormon reproduksi. Produksi hormon reproduksi yang tidak seimbang akan menyebabkan gangguan pada siklus menstruasi. ${ }^{3} \quad$ Salah satu gangguan yang dialami wanita sebelum dan sesaat setelah terjadi menstruasi adalah Dysmenorrhea.

Dysmenorrhea merupakan salah satu keluhan paling umum yang dapat mempengaruhi kualitas hidup wanita. ${ }^{4}$ Dysmenorrhea terdiri dari dua jenis, yaitu Dysmenorrhea primer dan Dysmenorrhea sekunder. Dysmenorrhea primer ditandai oleh rasa sakit pada panggul dengan patofisiologi yang belum jelas dan sebagian besar dialami oleh wanita berusia kurang dari 20 tahun sampai siklus ovulasi stabil dan teratur sedangkan Dysmenorrhea sekunder disebabkan oleh adanya patologi pada alat-alat genital seperti endometriosis, salfingitis, fibroid, adenomiosis, peradangan tuba falopi dan sebagainya dan lebih umum terjadi pada wanita usia lebih dari 20 tahun. ${ }^{5}$ Dampak merugikan Dysmenorrhea yang timbul diantaranya meningkatnya ketidakhadiran kerja, meningkatnya ketidakhadiran sekolah, terbatasnya sosialisasi dan lebih tingginya konsumsi obat penenang. Penelitian di Pakistan dan India pada pelajar wanita didapatkan hasil bahwa terjadi peningkatan absensi pada remaja yang mengalami Dysmenorrhea., ${ }^{4,6}$

Prevalensi Dysmenorrhea primer dan gangguan siklus menstruasi pada kelompok remaja merupakan prevalensi tertinggi diantara kelompok usia lainnya. Penelitian di salah satu SMA di Jakarta menunjukkan prevalensi penderita Dysmenorrhea sebanyak 54.5\% pada usia 15-19 tahun. ${ }^{7}$ Hasil ini menunjukkan tingginya kasus Dysmenorrhea pada usia remaja khususnya di jenjang pendidikan SMA. Penelitian yang dilakukan di SMA Negeri 9 Semarang menunjukkan sebanyak $15 \%$ remaja mengalami overweight dan $8.75 \%$ remaja mengalami obesitas, namun prevalensi obesitas abdominal belum diketahui. ${ }^{8}$

Menurut beberapa penelitian, status gizi berhubungan dengan kejadian Dysmenorrhea dan mempengaruhi siklus menstruasi wanita. Status gizi yang dimaksud adalah indeks massa tubuh, lingkar pinggang dan rasio lingkar pinggang dan panggul. Namun pada beberapa penelitian lainnya ditemukan tidak ada hubungan antara status gizi dan kejadian Dysmenorrhea dan siklus menstruasi. ${ }^{10}$

\section{METODE}

Penelitian ini merupakan penelitian observasional dengan rancangan penelitian cross sectional. Populasi penelitian adalah remaja perempuan usia 15-19 tahun yang berada di SMA Kota Semarang. Pemilihan sekolah dilakukan secara purposive sampling dengan mempertimbangkan wilayah sub urban dari masing-masing sekolah. Penentuan subjek dilakukan dengan simple random sampling dengan besar sampel sebesar 73 sampel dalam 2 kelompok sehingga jumlah keseluruhan sampel dalam penelitian ini adalah 146 orang. Variabel bebas dalam penelitian ini adalah obesitas sentral dan variabel terikatnya adalah siklus menstruasi dan Dysmenorrhea primer.

Pemilihan sampel dilakukan berdasarkan kriteria inklusi dan kriteria eksklusi. Kriteria inklusi dari penelitian ini yaitu terdaftar sebagai siswa di SMA 9 dan SMA 15 Semarang, berjenis kelamin perempuan, mengalami obesitas sentral (lingkar pinggang $\geq 80 \mathrm{~cm}$ ) dan normal (lingkar pinggang < $80 \mathrm{~cm}$ ) , sudah mengalami menstruasi, tidak mengkonsumsi alkohol dan rokok, mengetahui waktu atau tanggal menstruasi setiap bulannya, dan bersedia menjadi subyek penelitian dengan mengisi informed consent. Sedangkan kriteria eksklusinya adalah memiliki aktivitas fisik tinggi $(\geq 3000$ Metmenit/minggu) dan memiliki riwayat Dysmenorrhea keluarga.

Tahapan dalam penelitian ini meliputi skrining, pengisian kuesioner siklus mestruasi dan Dysmenorrhea primer, analisis data, dan pembuatan laporan. Proses skrining dilakukan untuk menentukan remaja yang memiliki status gizi kategori obesitas sentral dan remaja yang memiliki status gizi ( lingkar pinggang ) normal. Tahap skrining meliputi pengukuran antropometri seperti tinggi badan (TB), berat badan (BB) dan lingkar pinggang (LP) serta pengukuran aktivitas fisik dan riwayat Dysmenorrhea.

Pengukuran tinggi badan menggunakan microtoise, pengukuran berat badan menggunakan timbangan digital dan pengukuran lingkar pinggang menggunakan metline dilakukan pada bagian tengah antara tulang pelvis iliaka dan kosta paling akhir sedangkan pengukuran aktivitas fisik dan riwayat Dysmenorrhea keluarga menggunakan kuesioner aktivitas fisik GPAQ dan kuesioner riwayat Dysmenorrhea keluarga.

Subjek yang memenuhi kriteria inklusi selanjutnya dipilih secara acak sesuai jumlah masingmasing kelompok. Subjek yang sudah terpilih akan diminta untuk mengisi kuesioner tentang siklus 
menstruasi dan Dysmenorrhea primer. Siklus menstruasi dikategorikan dalam 2 kelompok, yaitu siklus menstruasi normal dan siklus menstruasi tidak normal. Siklus menstruasi yang masuk dalam kategori normal adalah siklus menstruasi yang terjadi dalam rentang waktu 21-35 hari. Siklus menstruasi yang masuk dalam kelompok siklus menstruasi yang tidak normal adalah siklus menstruasi yang kurang dari 21 hari dan lebih dari 35 hari serta terjadi selama dua kali atau lebih yang termasuk diantaranya tidak terjadinya menstruasi dalam dua bulan atau lebih dan mengalami menstruasi lebih dari sekali pada bulan tertentu.

Dysmenorrhea primer merupakan merupakan gangguan ginekologi yang ditandai oleh rasa sakit pada panggul dengan patofisiologi yang belum jelas dan sebagian besar dialami oleh wanita berusia kurang dari 20 tahun sampai siklus ovulasi stabil dan teratur yang ditandai dengan rasa kram pada bagian bawah abdomen dan dapat menjalar sampai bagian belakang kaki atau punggung bagian bawah dan biasa dilihat dari kebutuhan akan pengobatan dan ketidakmampuan dalam melakukan aktivitas. Subjek dikelompokkan dalam dua kelompok, yaitu kelompok penderita Dysmenorrhea primer dan kelompok normal menggunakan kuesioner Dysmenorrhea primer. Analisis data pada penelitian ini menggunakan uji Chi-square.

\section{HASIL PENELITIAN \\ Penelitian awal}

Penelitian awal dilakukan terhadap 385 remaja perempuan usia 15-19 tahun di SMA Negeri 9 dan SMA Negeri 15 Semarang yang merupakan tahapan skrining sehingga didapatkan angka kejadian untuk masing-masing kelompok remaja obesitas sentral dan remaja dengan status gizi normal. Gambaran status gizi remaja perempuan dalam dua kelompok ditampilkan pada tabel 1.

Tabel 1. Karakteristik Status Gizi Subjek

\begin{tabular}{|c|c|c|c|}
\hline Status Gizi & SMA 9 & SMA 15 & Total \\
\hline Obesitas sentral & $43(20.5 \%)$ & $38(21.7 \%)$ & $81(21 \%)$ \\
\hline Normal & $167(79.5 \%)$ & $137(78.2 \%)$ & $304(79 \%)$ \\
\hline Total & 210 & 175 & 385 \\
\hline
\end{tabular}

Berdasarkan hasil penyaringan terhadap 385 remaja perempuan dari kedua SMA, ditemukan sebanyak $21 \%$ remaja mengalami obesitas sentral dengan lingkar pinggang $\geq 80 \mathrm{~cm}$. Persentasi remaja perempuan yang mengalami obesitas sentral antara dua sekolah tidak jauh berbeda yaitu selisih $1.2 \%$.
Prevalensi obesitas sentral remaja perempuan ditemukan lebih tinggi di SMA 15 Semarang.

\section{Karakteristik Subjek}

Penelitian ini dilakukan pada 73 remaja obesitas sentral dan 73 remaja dengan lingkar pinggang normal. Adapun karakterisitik subjeknya adalah sebagai berikut.

Tabel 2. Karakteristik Subjek Berdasarkan Usia dan Nilai Antropometri

\begin{tabular}{lccccc}
\hline \multirow{2}{*}{\multicolumn{1}{c}{ Karakteristik }} & \multicolumn{2}{c}{ Normal $(\mathbf{n = 7 3})$} & \multicolumn{2}{c}{ Obesitas sentral $(\mathbf{n = 7 3})$} & \multirow{2}{*}{$\boldsymbol{p}$} \\
\cline { 2 - 4 } & Mean & SD & Mean & SD & \\
\hline Usia & 16.6 & 0.64 & 16.58 & 0.65 & 0.882 \\
Berat Badan $(\mathrm{Kg})$ & 48.4 & 6.03 & 70.66 & 13.43 & 0.001 \\
Tinggi Badan $(\mathrm{cm})$ & 154.02 & 6.18 & 157.68 & 5.47 & 0.001 \\
Lingkar pinggang $(\mathrm{cm})$ & 70.47 & 4.81 & 88.15 & 7.99 & 0.001 \\
\hline
\end{tabular}

Tabel 2 menunjukkan bahwa ada perbedaan yang bermakna pada berat badan, tinggi badan dan lingkar pinggang subjek antara kelompok obesitas sentral dan kelompok normal. Namun tidak ditemukan perbedaan yang bermakna pada umur subjek antara masing-masing kelompok.

Tabel 3. Analisis bivariat siklus menstruasi dan Dysmenorrhea Primer berdasarkan obesitas sentral

\begin{tabular}{|c|c|c|c|c|}
\hline \multirow[b]{2}{*}{ Status Gizi } & \multicolumn{2}{|c|}{ Siklus menstruasi } & \multicolumn{2}{|c|}{ Dysmenorrhea primer } \\
\hline & $\begin{array}{c}\text { Tidak normal } \\
(\%)\end{array}$ & Normal (\%) & $\begin{array}{c}\text { Dysmenorrhea } \\
\text { primer }(\%)\end{array}$ & Normal (\%) \\
\hline Obesitas Sentral & $23(31.5)$ & $50(68.4)$ & $20(27.3)$ & $53(72.6)$ \\
\hline Normal & $10(13.6)$ & $63(86.3)$ & $15(20.5)$ & $58(79.4)$ \\
\hline$p$ & \multicolumn{2}{|c|}{0.018} & \multicolumn{2}{|c|}{$\mathbf{0 . 4 3}$} \\
\hline
\end{tabular}




\section{Hubungan obesitas sentral dengan siklus menstruasi}

Tabel 3 menunjukkan hasil bahwa ada hubungan antara obesitas sentral dengan siklus menstruasi, dimana remaja yang menderita obesitas sentral dan mengalami siklus menstruasi tidak normal sebesar $31.5 \%$ sedangkan remaja dengan lingkar pinggang normal dengan siklus menstruasi tidak normal hanya $13.6 \%$.

\section{Hubungan obesitas sentral dengan kejadian Dysmenorrhea primer}

Tabel 3 menunjukkan hasil bahwa tidak ada hubungan antara obesitas sentral dengan kejadian Dysmenorrhea primer $(p>0.05)$. Tetapi jika dilihat dari persentasinya, kelompok obesitas sentral cenderung mengalami kejadian Dysmenorrhea primer lebih tinggi dengan persentasi $27.3 \%$ dibandingkan kelompok status gizi (lingkar pinggang) normal sebesar $20.5 \%$.

Tabel 4. Siklus menstruasi dan Dysmenorrhea primer pada masing-masing kelompok

\begin{tabular}{lccc}
\hline \multirow{2}{*}{ Keluhan } & \multicolumn{2}{c}{ Status Gizi } & \multirow{2}{*}{ Total } \\
\cline { 2 - 3 } & Obesitas sentral & Normal & \\
\hline Normal & 38 & 51 & 89 \\
Dysmenorrhea primer & 12 & 12 & 24 \\
Siklus menstruasi tidak normal & 15 & 7 & 22 \\
Dysmenorrhea primer+Siklus tidak normal & 8 & 3 & 11 \\
\hline \multicolumn{1}{c}{ Total } & 73 & 73 & 146 \\
\hline
\end{tabular}

Tabel 4 menunjukkan hasil bahwa sebanyak 11 remaja mengalami siklus menstruasi tidak normal dan Dysmenorrhea primer. Remaja kelompok obesitas sentral yang mengalami siklus menstruasi yang tidak normal dan Dysmenorrhea primer sebanyak 8 orang sedangkan pada kelompok lingkar pinggang normal sebanyak 3 orang. Jumlah ini terlihat lebih tinggi pada kelompok obesitas sentral dibandingkan dengan remaja kelompok normal.

Tabel 4 menunjukkan hasil bahwa tidak ada hubungan antara siklus menstruasi dan Dismenorrhea primer $(p>0.05)$.

Tabel 5. Analisis bivariat siklus menstruasi dengan Dysmenorrhea primer

\begin{tabular}{lccc}
\hline \multirow{2}{*}{ Siklus menstruasi } & \multicolumn{2}{c}{ Status Dysmenorrhea } & \multirow{2}{*}{$\boldsymbol{p}$} \\
\cline { 2 - 3 } & Dysmenorrhea primer & Normal & \multirow{2}{*}{0.23} \\
\hline Tidak normal & $11(7.5 \%)$ & $22(15.1 \%)$ & \\
Normal & $24(16.4 \%)$ & $89(61.0 \%)$ & \\
\hline \multicolumn{1}{c}{ Total } & $35(24.0 \%)$ & $111(76.0 \%)$ & \\
\hline
\end{tabular}

Tabel 6. Karakteristik Dysmenorrhea primer berdasarkan usia

\begin{tabular}{cccccc}
\hline \multirow{2}{*}{ Usia (th) } & \multicolumn{2}{c}{ Dysmenorrhea primer } & \multicolumn{2}{c}{ Normal } & \multirow{2}{*}{ Total } \\
\cline { 2 - 5 } & $\mathbf{n}$ & $\mathbf{\%}$ & $\mathbf{n}$ & $\mathbf{\%}$ & \\
\hline 15 & 7 & 30.4 & 16 & 69.6 & 23 \\
16 & 21 & 27.3 & 56 & 72.7 & 77 \\
17 & 7 & 15.2 & 39 & 84.8 & 46 \\
\hline Total & $\mathbf{3 5}$ & $\mathbf{2 4}$ & $\mathbf{1 1 1}$ & $\mathbf{7 6}$ & $\mathbf{1 4 6}$ \\
\hline
\end{tabular}

Tabel 6 menunjukkan bahwa remaja penderita Dysmenorrhea primer tertinggi ada pada usia 15 tahun. Hasil ini terlihat dari nilai persentase penderita Dysmenorrhea lebih tinggi pada usia ini.

\section{PEMBAHASAN}

Hasil penelitian menunjukkan dari 385 remaja perempuan yang diskrining di kedua SMA ditemukan sebanyak $21 \%$ remaja mengalami obesitas sentral dengan lingkar pinggang $\geq 80 \mathrm{~cm}$. Hasil ini lebih rendah jika dibandingkan dengan data Hasil Riset Kesehatan Dasar Nasional 2013 dimana prevalensi obesitas sentral sebesar $26.6 \%$. Terjadi peningkatan prevalensi obesitas sentral dari tahun 2007 yang hanya sebesar $18.8 \% .{ }^{11}$ Sedangkan Hasil Riset Kesehatan Dasar Provinsi Jawa Tengah 2013 menunjukkan prevalensi obesitas sentral yang lebih tinggi pada wanita yaitu $39.4 \%$ dan pada kelompok usia 15-24 tahun sebesar $9.5 \% .^{12}$

Obesitas sentral adalah kondisi kelebihan lemak yang terpusat pada daerah perut (intra abdominal fat). Hal ini terjadi karena asupan makanan berlebih yang tidak dibarengi dengan aktifitas fisik yang seimbang atau sedentary life style. ${ }^{13}$ Jaringan lemak visceral memiliki sel per unit massa lebih banyak, aliran darah lebih tinggi, reseptor 
glukokortikoid (kortisol), androgen (testosteron) lebih banyak dan katekolamin lebih besar dibandingkan jaringan lemak bawah kulit. ${ }^{14}$ Akumulasi lemak pada daerah perut yang terlalu tinggi memicu jaringan adiposa menghasilkan hormon dalam jumlah yang tidak normal, seperti tingginya sekresi insulin, tingginya level testosterone dan androstenedion bebas, dan rendahnya level progesterone. Tingginya level testosterone bebas dan level insulin yang terikat menstimulasi produksi androgen pada jaringan ovarium yang mengganggu ovulasi normal dan menyebabkan kelainan menstruasi. Obesitas khususnya obesitas sentral menyebabkan timbulnya keadaan hiperinsulinemia dan resistensi insulin. Perubahan metabolisme insulin menyebabkan penurunan SHBG (sex hormonebinding globulin), hiperandrogenemia, dan gangguan pada fungsional sistem IGF, sehingga meningkatkan kejadian gangguan menstrual dan ovulatorik. ${ }^{8,15}$

Hasil penelitian ini menunjukkan ada hubungan yang bermakna antara obesitas sentral dengan siklus menstruasi. Subjek yang mengalami obesitas sentral berisiko mengalami siklus menstruasi tidak normal lebih tinggi dibandingkan dengan subjek dengan status gizi normal ( lingkar pinggang $<80$ $\mathrm{cm})$. Hasil ini lebih tinggi jika dibandingkan dengan penelitian pada mahasiswi di Mesir pada tahun 2014 dimana prevalensi wanita yang memiliki siklus menstruasi tidak normal hanya sebesar $15.9 \% .{ }^{9}$ Hasil penelitian ini sejalan dengan penelitian pada wanita usia 26-36 tahun yang dilakukan di Australia, yang menyatakan bahwa obesitas sentral berhubungan dengan ketidakteraturan siklus menstruasi dimana wanita dengan obesitas sentral cenderung memiliki siklus menstruasi yang lebih panjang. ${ }^{16}$

Obesitas sentral menggambarkan komposisi lemak tubuh yang berpusat pada daerah perut yang berhubungan dengan tingkat hormonal. Ketidakteraturan menstruasi berhubungan positif dengan testosteron, FAI (free androgen index), dan nilai insulin tinggi dan berhubungan negatif dengan SHBG. Insulin dan SHBG menjadi penyebab adanya hubungan antara obesitas dan ketidakteraturan menstruasi, terlihat dari literatur yang menunjukkan bahwa peningkatan kadar insulin menyebabkan penurunan kadar SHBG. ${ }^{16}$ Obesitas dihubungkan dengan tingkat pembentukan esterogen melalui konversi androgen menjadi esterogen dalam bentuk androstenedion yang terjadi dalam jaringan adiposa oleh enzim aromatase. ${ }^{14}$ Proses pembentukan esterogen dari androgen dalam jaringan adiposa akan meningkat sejalan dengan persentasi jaringan lemak tubuh yang tinggi. Esterogen yang tinggi akan menyebabkan gangguan keseimbangan hormon di dalam tubuh sehingga menyebabkan gangguan siklus menstruasi. ${ }^{17}$
Wanita dengan obesitas sentral memiliki tingkat konsentrasi SHBG yang lebih rendah dalam perbandingan usia dan berat badan pada obesitas peripheral. Hal ini terjadi karena lebih tingginya sirkulasi insulin pada wanita dengan obesitas sentral yang menghambat pembentukan SHBG di hati. ${ }^{18}$ Ketidakteraturan menstruasi menjadi tanda resistensi insulin, dimana salah satu gangguan siklus menstruasi Oligomenorrhea berhubungan dengan hiperinsulin yang dimasa mendatang akan meningkatkan risiko Diabetes Mellitus. Wanita dengan menstruasi yang abnormal memiliki risiko lebih tinggi terhadap infertilitas, penyakit jantung dan pembuluh darah dan DM tipe 2. ${ }^{19}$ Gangguan yang terjadi pada organ reproduksi juga dapat ditandai oleh siklus menstruasi yang tidak normal.

Hasil penelitian ini menunjukkan obesitas sentral tidak memiliki hubungan yang bermakna dengan Dysmenorrhea primer $(p>0.05)$, namun kejadian Dysmenorrhea primer cenderung lebih tinggi pada kelompok obesitas sentral meskipun uji statistik menunjukkan hasil yang tidak bermakna. Hasil penelitian ini sejalan dengan penelitian yang dilakukan di Mesir pada wanita usia 17-19 tahun yang menyatakan tidak ada hubungan yang bermakna antara status gizi dan Dysmenorrhea. ${ }^{9}$ Penelitian serupa dilakukan pada wanita usia 18-28 tahun di India Selatan dan ditemukan tidak ada hubungan yang bermakna antara Dysmenorrhea primer dengan status gizi. ${ }^{20}$ Namun status gizi yang dilihat di penelitian ini adalah indeks massa tubuh ( IMT ). Hasil ini berbeda dengan penelitian yang dilakukan di kota Medan yang menyatakan ada hubungan yang bermakna antara obesitas dan Dysmenorrhea primer. ${ }^{21}$

Dysmenorrhea primer terjadi karena produksi prostaglandin, vasopressin dan substatnsi kimia dari phospholipid yang berlebihan atau tidak seimbang. Peningkatan serum progesterone yang mengikuti proses ovulasi menyebabkan meningkatnya asam arakidonat yang merupakan prekursor prostaglandin, prostasiklin dan thromboxane A2 yang menyebabkan kontraksi uterus dan berperan sebagai vasokontriktor. ${ }^{22}$ Status gizi berlebih dapat menyebabkan Dysmenorrhea primer melalui hiperplasi pembuluh darah atau terdesaknya pembuluh darah oleh jaringan lemak yang berlebihan pada organ reproduksi wanita, sehingga darah yang harusnya mengalir pada proses menstruasi terganggu dan mengakibatkan nyeri pada saat menstruasi. ${ }^{21}$ Wanita yang mengalami obesitas sentral atau memiliki berat badan berlebih cenderung memiliki lemak yang berlebih yang dapat memicu produksi hormon reproduksi berlebih yang dapat mengganggu system reproduksi pada saat menstruasi sehingga menimbulkan nyeri. ${ }^{21}$ 
Faktor lain yang mempengaruhi wanita obesitas mengalami Dysmenorrhea primer adalah asam lemak yang berlebihan di dalam tubuh yang dapat mengganggu metabolisme progesteron pada fase luteal dari siklus menstruasi. Akibatnya terjadi peningkatan kadar prostaglandin yang akan menyebabkan rasa nyeri pada saat Dysmenorrhea. Setelah ovulasi terjadi penumpukan asam lemak pada bagian fospolipid pada sel membran. Kadar progesteron yang menurun sebelum haid diikuti oleh pelepasan asam lemak yaitu asam arakidonat yang selanjutnya mengalami reaksi berantai menjadi prostaglandin yang dapat menimbulkan rasa nyeri saat haid. ${ }^{23}$ Namun hasil penelitian ini berbeda dengan teori yang ada dimana tidak ditemukan hubungan yang bermakna antara obesitas sentral dan Dysmenorrhea primer. Hal ini dapat disebabkan karena ada subjek yang tidak mengetahui riwayat Dysmenorrhea keluarga dan adanya faktor stress yang tidak diukur dalam penelitian ini. ${ }^{24}$ Dampak yang dapat ditimbulkan oleh Dysmenorrhea primer adalah terjadinya penurunan produktivitas dan meningkatnya absensi wanita pada jam sekolah dan jam kerja.

Jumlah subjek yang mengalami siklus menstruasi tidak normal juga mengalami Dysmenorrhea primer adalah 11 orang, dimana jumlah tertinggi ada pada kelompok obesitas sentral sebanyak 8 orang dan 3 orang pada kelompok lingkar pinggang normal. Tidak ada hubungan yang bermakna antara siklus menstruasi dan Dysmenorrhea primer. Hasil penelitian ini sejalan dengan penelitian yang dilakukan pada remaja di Medan bahwa tidak ada hubungan antara siklus menstruasi dan Dysmenorrhea primer. ${ }^{21}$ Siklus menstruasi lebih dihubungkan pada Dysmenorrhea skunder yang disebabkan oleh endometriosis. Beberapa gejala yang ditimbulkan pada endometriosis adalah pendarahan yang lebih banyak pada saat menstruasi, pendarahan diluar waktu menstruasi, menstruasi yang tidak teratur dan nyeri pada daerah pelvic. ${ }^{25}$ Kondisi siklus menstruasi yang tidak normal diikuti oleh Dysmenorrhea primer mungkin saja terjadi karena adanya Dysmenorrhea sekunder yang belum terdiagnosis karena untuk menegakkan diagnosis Dysmenorrhea sekunder harus dilakukan pemeriksaan medis.

Dysmenorrhea primer terlihat lebih tinggi pada usia subjek termuda yaitu usia 15 tahun dan semakin menurun semakin bertambahnya usia. Usia remaja awal erat kaitannya dengan ketidakstabilan emosional dan organ reproduksi yang masih berkembang sehingga lebih cenderung mengalami emosional. Selain itu ketidaksiapan remaja dalam menghadapi pertumbuhan dan perkambangan diri mengakibatkan gangguan psikis yang akhirnya menyebabkan gangguan siklus menstruasi dan Dysmenorrhea primer. $^{21,26}$ Ketahanan seseorang terhadap nyeri juga semakin tinggi dengan bertambahnya usia dimana wanita yang mengalami menstruasi lebih lama akan memiliki ketahanan lebih tinggi terhadap nyeri dibandingkan dengan wanita yang baru mengalami menstruasi. ${ }^{26} \mathrm{Hal}$ ini dapat menjadi salah satu alasan tidak adanya hubungan antara obesitas sentral dan Dysmenorrhea primer.

\section{SIMPULAN}

Terdapat hubungan yang bermakna antara obesitas sentral dengan siklus menstruasi pada remaja. Siklus menstruasi tidak normal lebih tinggi pada kelompok remaja obesitas sentral.

\section{SARAN}

Obesitas sentral memiliki hubungan yang bermakna dengan siklus menstruasi, dimana obesitas sentral menyebabkan siklus menstruasi tidak normal pada remaja. Oleh sebab itu, remaja yang mengalami obesitas sentral disarankan menurunkan berat badan agar mendapatkan berat badan ideal sehingga siklus menstruasi tidak normal dapat dihindari.

\section{DAFTAR PUSTAKA}

1. Bays H. Central obesity as a clinical marker of adiposophaty; increased viceral adiposity as a surrogate marker or global fat dysfunction. Louisville Metabolic and Atherosclerosis Research Center. 2014;21:345-351.

2. Mihm M, Gangooly S, Muttukrishna S. The normal menstrual cycle in women. Anim Reprod Sci [Internet]. Elsevier B.V. 2011;124(3-4):229-36.

3. Kocelak P, Chudek J, Naworska B, Sosnowska MB, Kotlarz B, Mazurek $M$ et al. Psycological disturbances and quality of life in obese and infertile women and men. International Journal of Endocrinology. 2012;1-14.

4. Habibi N, Huang MS, Gan WY, Zulida R, Safavi SM. Prevalence of Dysmenorrhea and factor associated with its intensity among undergraduate student: a cros-sectional study. American Society for Pain Management Nursing. 2015;16(6):855-61.

5. Ju H, Jones M, Mishra G. The prevalense and risk factors of Dysmenorrhea. Oxford University Press on behalf of the Johns Hopkins Bloomberg School of Public Health. 2014;36(7):104-13.

6. Gulzar S, Khan S, Abbas K, Arif S, Husain SS, Imran H et al. Prevalence, perceptionand effect of Dysmenorrhea in school going female aldoscent of Karachi, Pakistan. International Journal of Innovative Research and Development. 2015;236-4.

7. Sianipar O, Bunawan NC, Almazini P, Calista N, Wulandari P, Rovenska $\mathrm{N}$ et al. Prevalensi gangguan menstruasi dan faktor-faktor yang berhubungan pada siswi SMU di Kecamatan Pulo Gadung Jakarta Timur. MKI. 2009;59(6):308-313

8. Oktaviani W, Saraswati L, Rahfiludin M. Hubungan kebiasaan konsumsi fast food, aktivitas fisik, pola 
konsumsi, karakteristik remaja dan orang tua dengan indeks massa tubuh (IMT) (studi kasus pada siswa SMA Negeri 9 Semarang tahun 2012). Jurnal Kesehatan Masyarakat. 2012;2(1):542-553

9. Nooh AM. Menstrual disorders among Zagazig University. Middle East Fertility Society. 2015;20(3):198-203.

10. Novia I, Puspitasari N. Faktor risiko yang mempengaruhi kejadian Dismenore Primer. The Indonesian Journal of Public Health. 2008; 4(2): 96104

11. Balitbang Kemenkes RI. Riset Kesehatan Dasar. Jakarta: Balitbang Kemenkes RI;2013.

12. Balitbang Kemenkes RI. Riset Kesehatan Dasar Dalam Angka Provinsi Jawa Tengah. Jakarta: Balitbang Kemenkes RI;2013.

13. Listiyana A, Mardiana, Prameswari G. Obesitas sentral dan kadar kolesterol total. Jurnal Kesehatan Masyarakat. 2013;9(1):37-43

14. Seif MW, Diamond K, Nickkho-amiry M. Best Practice \& Research Clinical Obstetrics and Gynaecology Obesity and menstrual disorders. Elsevier Ltd. 2015;29(4):516-27.

15. Harkness L, Burnside M, Bonny A. Sensitivity and specificity of waist circumference and BMI for predicting fatness in male and female adolescents. The FASEB journal. 2006 20:(11)

16. Wei S, Schmidt M, Dwyer T, Norman R, Venn A. Obesity and Menstrual Irregularity: Associations With SHBG, Testosterone, and Insulin.Obesity Journal. 2009; 5(17):1070-1076

17. Rakhmawati A, Dieny F. Hubungan obesitas dengan kejadian gangguan siklus menstruasi pada wanita dewasa muda. Journal of Nutrition College. 2013;2:214-22.

18. Pasquali R, Pelusi C, Genghini S, Cacciari M. Obesity and reproductive disorders in women. European Society of Human Reproduction and Embryology. 2003;9(4):359-72.

19. Salomon CG, Frank B, Dunaif A, Edwar JR, Stampfer M,Willet WC et al. Menstrual cycle irregularity and risk for future cardiovascular disease. The Jurnal of Clinical Endcrinology and Metabolism. 2002;87(5):2013-2017

20.Omdivar S, Begum K. Characteristics and determinants of primary Dysmenorrhea in young adults. American Medical Journal. 2012;3(1):8-13

21. Sophia F, Muda S, Jemadi. Faktor - faktor yang berhubungan dengan dismenore pada siswi SMK Negeri 10 Medan. The Indonesian Journal of Public Health. 2013;1-10.

22. Morrow C, Naumburg EH. Dysmenorrhea. Department of Community and Family Medicine. 2009;36:19-32.

23. Larasati TA, Alatas F. Dismenore primer dan faktor risiko Dismenore primer pada Remaja. Majority. 2016;3(5):79-84

24. Ammar UR. Faktor risiko Dismenore primer pada wanita usia subur di Kelurahan Ploso Kecamatan Tambaksari Surabaya. Jurnal Berkala Epidemiologi. 2016;4(1):37-49

25. Suparman E. Penatalaksanaan Endometriosis. Jurnal Biomedik. 2012;4(2):69-78
26. Wiknjosastro, Hanifa. 2005. Ilmu kebidanan Edisi Ketiga. Jakarta: Yayasan Bina Pustaka Sarwono Prawirohardjo 